\title{
Experience on Earthquake Safety of Large Embankment Dams Constructed in Turkey
}

\author{
Hasan Tosun ${ }^{1}$ \\ ${ }^{1}$ Eskisehir Osmangazi University, Engineering and Architecture Faculty \\ Bati Meselik, Eskisehir, Turkey \\ htosun@ogu.edu.tr
}

\begin{abstract}
Strong ground shaking results in the instability of the embankment and loss of strength at the foundations. Earthquakes can result in damages or failures for dam structures, while dams with large reservoirs can induce to earthquakes. Earthquake safety assessment is an important phenomenon in dam engineering and requires more comprehensive seismic studies for understanding the seismic behavior of dams subjected to severe earthquakes. Seismic hazard and seismic design are important aspects for large dam projects. Case studies about the seismic performance of dams under large earthquakes are available in the literature. Especially active faults on or near dam sites can cause to damaging deformation of the embankment. Turkey has so many dams, which are under the influence of near source zone. This study outlines stability analyses of large embankment dams located on active seismic area, discusses the experience on behavior of large embankment dams located on or near active faults in Turkey and introduces results of total risk analyses of the case studies including large embankment dams, namely Ataturk, Altinkaya, Catalan, Ilisu, Keban, Kilickaya, Menzelet, which have structural heights of 70 to $207 \mathrm{~m}$.
\end{abstract}

Keywords: Embankment dam, earthquake, seismic hazard, total risk

\section{Introduction}

Design engineers have learned from case studies that embankment dams should withstand the design earthquake without damages or with little damages of acceptable level. Turkey is located on one of the most seismically active regions in the world. Major earthquakes with the potential of threatening life and property occur frequently here. Significant structural damage had developed at a number of dams, but no failures have been reported. The well-known case to earthquake damage for an embankment dam in Turkey occurred during the 1986 Dogansehir earthquake with Ms of 5.8. The epicenter of earthquake was very close to the dam and the damages to the structure were a result of the strong motion of the nearby fault $[1,2,3,4,5]$. Since there are many dams under the influence of near-source zones in Turkey, meaningful seismic parameters are needed to perform a satisfactory evaluation of the dams. However, a special technique should be adopted for reevaluation of existing dams. Tosun and co-workers [6,7] state that type of dam is very important factor acting on seismic assessment for existing large dam.

There are twenty-six water basin in Turkey. State organizations and private companies try to utilize their hydraulic capacities by cascade dams, which affect river hydrology as well as public safety of people living downstream. The appropriate design measures should be considered to obtain rational solution to the problem such as catastrophic release of water from the reservoir. Therefore, total risk is an important aspect for all dams in the system. Earthquake safety of existing dams is one of significant factors acting total stability of the system. In Turkey, there are so many deep valleys to construct cascade structures, which are under operation stage in Turkey. For example, Upper Euphrates basin having more than twenty-five cascade dams located at upstream part of Keban reservoir, which is main key structure in this system.

Authors and co-workers have so many research studies for structures discussed here $[8,9,10,11,12,13,14$, $15,16,17,18,19,20]$. This paper summaries experience on seismic design for existing large embankment dams and deals with an evaluation of seismic hazard and local site effects and evaluates seven selected large embankment dams, which have a structural height greater than $130 \mathrm{~m}$, in the main rivers of six basins. Each of these dams are the most critical structure for its basin. Table 1 introduces the physical properties of the related structures. Five of them have been designed as rockfill and earthfill types, while another one has a type of concrete faced rockfill dam. There is also a composite type, considered in this study, combining types of concrete gravity and rockfill. 
Table 1. Large Embankment Dams considered in the study

\begin{tabular}{|l|l|c|c|c|c|c|r|r|r|}
\hline$\#$ & Dam & Basin & Aim $\left(^{*}\right)$ & $\begin{array}{c}\text { Completed } \\
\text { Year }\end{array}$ & $\begin{array}{c}\text { Type } \\
(* *)\end{array}$ & $\begin{array}{c}\text { Height } \\
\text { from } \\
\text { river } \\
\text { bed } \\
(\mathrm{m})\end{array}$ & $\begin{array}{c}\text { Height } \\
\text { from } \\
\text { foundation } \\
(\mathrm{m})\end{array}$ & $\begin{array}{c}\text { Volume of } \\
\text { embankment } \\
\left(\mathrm{m}^{3}\right) \\
\left.\mathrm{X}^{3}\right)\end{array}$ & $\begin{array}{c}\text { Volume } \\
\text { of } \\
\text { reservoir } \\
\left(\mathrm{hm}^{3}\right)\end{array}$ \\
\hline 1 & Ataturk & Euphrates & E+I+D & 1992 & RF & 166 & 169 & 84500 & 48700 \\
\hline 2 & Altinkaya & Kizilirmak & E & 1988 & RF & 137 & 195 & 15920 & 5763 \\
\hline 3 & Catalan & Seyhan & E+I+F & 1996 & EF & 70 & 82 & 14500 & 2120 \\
\hline 4 & Ilisu & Tigris & E+I+F & 2020 & CFRD & 135 & 130 & 23760 & 10400 \\
\hline 5 & Keban & Euphrates & E+I & 1974 & RF+CG & 163 & 207 & 15585 & 31000 \\
\hline 6 & Kilickaya & Yesilirmak & E+F & 1990 & RF & 103 & 134 & 7000 & 1400 \\
\hline 7 & Menzelet & Ceyhan & E & 1992 & EF & 137 & 151 & 8700 & 1975 \\
\hline
\end{tabular}

(*) $\mathrm{E}=$ Energy $\mathrm{I}=$ Irrigation $\mathrm{F}=$ Flood control $\mathrm{D}=$ Domestic Water

(**) $\mathrm{EF}=$ Earthfill $\mathrm{RF}=$ Rockfill $\mathrm{CG}=$ Concrete Gravity CFRD $=$ Concrete Faced Rockfill Dam

\section{Methodology}

Seismic hazard is the main factor acting on the total risk of dam structures. The seismic hazard of a dam site can be based on the peak ground acceleration (PGA). For the seismic hazard analysis of a particular site, all possible seismic sources were identified and their potential was evaluated in detail, as based on the guidelines given by Fraser and Howard [21] and the unified seismic hazard modelling for Mediterranean region introduced by Jiminez et. al [22]. Due to the unavailability of strong motion records, various attenuation relationships were adopted to calculate the peak ground acceleration (PGA) acting on dam sites. For this study six separate predictive relationships for horizontal peak ground acceleration were considered $[23,24,25,26,27,28]$.

The study of seismic activity includes deterministic and probabilistic seismic hazard analyses. Kramer [29] states that the probabilistic seismic hazard analysis provides a framework in which uncertainties can be identified and combined in a rational manner to provide a more complete picture of the seismic hazard. Krinitzsky [30] states that deterministic seismic hazard analysis considers geology and seismic history to identify earthquake sources and to interpret the strongest earthquake with regardless of time.

The Operating Basis Earthquake (OBE) was defined by means of the probabilistic methods mentioned above. It is known as the earthquake that produces the ground motions at the site that can reasonably be expected to occur within the service life of the project. Maximum Credible Earthquake (MCE), which is the largest earthquake magnitude that could occur along a recognized fault or within a particular seismo-tectonic province or source area under the current tectonic framework, was obtained for each zone, and the most critical framework for the dam site was selected as Controlling Maximum Credible Earthquake (CMCE). The Maximum Design Earthquake (MDE) was then defined. FEMA [31] states that MDE, which is normally characterized by a level of motion equal to that expected at the dam site from the occurrence of deterministically evaluated MCE and Safety Evaluation Earthquake (SEE), should be used for critical structures located in very active seismic area [32]. Most of large dams in Turkey were analyzed by using these definitions. For all analyses throughout this study, the peak ground acceleration was obtained by considering FEMA's earthquake definition by two methods.

The total risk for dam structures mainly depends on the seismic hazard rating of dam site and the risk rating of the dam structure. Throughout this study, two methods have been considered. In DSI guidelines, total risk factor depends to reservoir capacity, height, evacuation requirement and potential hazard [33]. The Bureau method [34], which considers dam type, age, size, downstream damage potential and evacuation requirements, was utilized to realize the risk analyses of the basin. It recommends four separate risk classes ranging from I (low risk) to IV (extreme risk) as based on the Total Risk Factor (TRF).

\section{Analyses}

Dam design engineers believe the fact that embankment dams, which are well compacted according to the specification, are suitable type for regions having high seismic activity. Whereas it is a well-known fact that strong ground shaking can 
result to instability on embankment and loss of strength at the foundations. Additionally, active faults, which are very close to the foundation of dams, have the potential to cause damaging displacement of the structure. In this study, seven existing large dams, which are the most critical dams for own basins, were analyzed to obtain their seismic positions and total risks.

A detailed study was performed to identify all possible seismic sources for the seismic hazard analyses of the dam sites, as based on the macro seismo-tectonic model prepared by the National Disaster Organization and other Institutes. However, it was modified by the author and his co-workers. Local geological features and seismic history were also taken into account to quantify the rate of seismic activity in dam sites. As a result of detailed evaluation, total area covering all basins was separated into nine seismic zones (Fig.1).

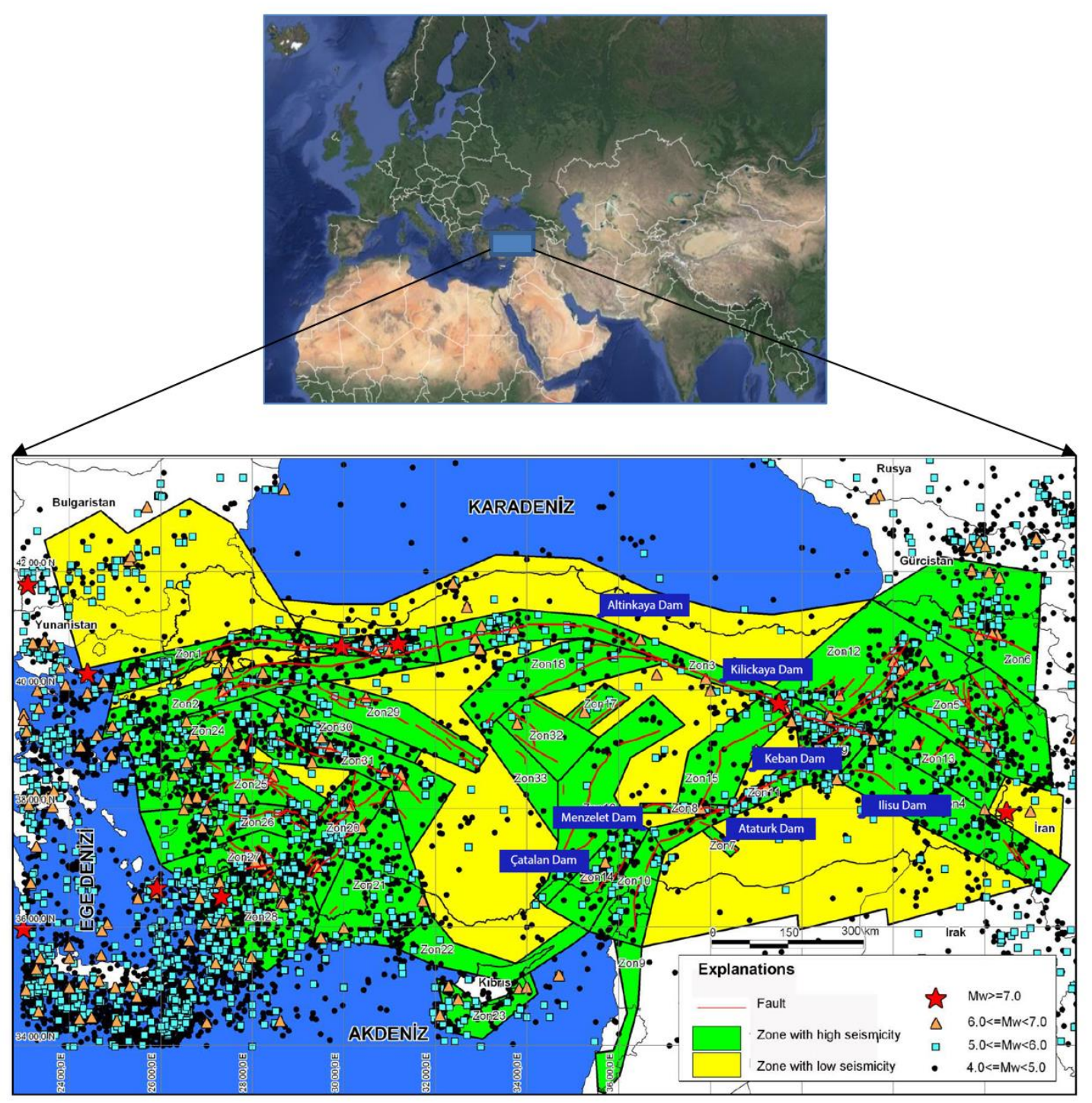

Figure 1. Seismo-tectonic map of Turkey and locations of dams considered in this study.

Most of the existing dams considered for this study are not under near source effect with exception of Ataturk, Kilickaya and Menzelet dams [35,36]. ICOLD [32] defined the near-field motion, which is ground motion recorded in the vicinity of a fault. Author established limits of near-field motion for the investigation area. According to this model, the maximum 
magnitude of the earthquakes ranges from 5.7 to 7.4 and the minimal distance to fault segment is between 1.3 and $44.0 \mathrm{~km}$ for seven dams. Ataturk, Kilickaya and Menzelet dams, can be categorized as "a dam under near source effect" when considered possible fault zone passing through near dam site. The 43 percent of dams considered for this study has a minimal distance, which is less than $10 \mathrm{~km}$ to an active fault.

The DSHA and PSHA results are summarized in Table 2. In this table, $\mathbf{M}_{\max }$ is the maximum earthquake magnitude in $M_{w}$ and $R_{\min }$ is the minimum distance to fault segment. For deterministic method, mean PGA $+50 \%$ and mean PGA $+84 \%$ are mean peak ground acceleration at the $50^{\text {th }}$ percentile and Mean Peak Ground Acceleration at the $84^{\text {th }}$ percentile, respectively. The OBE, MDE and SEE are respectively the Operation Based Earthquake, Maximum Design Earthquake and Safety Evaluation Earthquake for probabilistic method.

Table 2. Results of deterministic and probabilistic analyses

\begin{tabular}{|c|c|c|c|c|c|c|c|c|c|c|c|}
\hline \multirow[b]{2}{*}{ \# } & \multirow[b]{2}{*}{ Dam } & \multicolumn{4}{|c|}{ Deterministic Method * } & \multicolumn{3}{|c|}{ Probabilistic Method $* *$} & \multicolumn{3}{|c|}{ Total Risk (Bureau, 2003) } \\
\hline & & $M_{\max }$ & $\begin{array}{l}R_{\min } \\
(\mathrm{km})\end{array}$ & $\begin{array}{c}\text { Mean PGA } \\
+50 \% \\
\text { in } \mathrm{g}\end{array}$ & $\begin{array}{c}\text { Mean PGA } \\
+84 \% \\
\text { in } \mathrm{g}\end{array}$ & $\begin{array}{l}\text { OBE } \\
\text { in } g\end{array}$ & $\begin{array}{c}\text { MDE } \\
\text { in } g\end{array}$ & $\begin{array}{l}\text { SEE } \\
\text { in } g\end{array}$ & $\begin{array}{l}\text { Risk } \\
\text { factor }\end{array}$ & $\begin{array}{l}\text { Risk } \\
\text { class }\end{array}$ & $\begin{array}{l}\text { Risk } \\
\text { ratio }\end{array}$ \\
\hline 1 & Ataturk & 6.0 & 1.3 & 0.327 & 0.552 & 0.194 & 0.298 & 0.460 & 137.0 & III & High \\
\hline 2 & Altinkaya & 6.1 & 10.8 & 0.179 & 0.305 & 0.287 & 0.377 & 0.512 & 128.4 & III & High \\
\hline 3 & Catalan & 5.7 & 24.1 & 0.102 & 0.170 & 0.179 & 0.231 & 0.305 & 183.6 & III & High \\
\hline 4 & Ilisu & 6.8 & 19.8 & 0.161 & 0.273 & 0.212 & 0.268 & 0.349 & 139.0 & III & High \\
\hline 5 & Keban & 6.8 & 44.0 & 0.068 & 0.115 & 0.099 & 0.127 & 0.170 & 126.4 & III & High \\
\hline 6 & Kilickaya & 7.4 & 7.8 & 0.357 & 0.583 & 0.197 & 0.300 & 0.464 & 170.4 & III & High \\
\hline 7 & Menzelet & 6.1 & 8.2 & 0.206 & 0.350 & 0.271 & 0.375 & 0.532 & 192.3 & III & High \\
\hline
\end{tabular}

(*) $\mathrm{M}_{\text {maks }}=$ Maximum earthquake magnitude in $\mathrm{M}_{\mathrm{w}} ; \mathrm{R}_{\min }=$ Minimum distance to fault segment Mean PGA $+50 \%=$ Mean Peak Ground Acceleration at the $50^{\text {th }}$ percentile

Mean PGA $+84 \%=$ Mean Peak Ground Acceleration at the $84^{\text {th }}$ percentile

(**) $\mathrm{OBE}=$ Operational Based Earthquake; $\mathrm{MDE}=$ Maximum Design Earthquake; SEE $=$ Safety Evaluation Earthquake

The deterministic analyses indicate that the maximum values of peak ground acceleration (PGA) belong to Kilickaya dam. The PGA values ranges from $0.068 \mathrm{~g}$ to $0.386 \mathrm{~g}$ for the mean Peak Ground Acceleration at the $50^{\text {th }}$ percentile and from $0.115 \mathrm{~g}$ to $0.651 \mathrm{~g}$ for the mean Peak Ground Acceleration at the $84^{\text {th }}$ percentile. According to the updated DSI guidelines, the PGA values at the $84^{\text {th }}$ percentile should be taken into account for five dams analysed throughout the study, when considered deterministic approach [33].

The total analyses were performed for seven dams throughout this study. The results with total risk of each dam are given table 4. Four dams are identified in class of II with moderate hazard rating while other two ones are classified in class IV with high hazard rating. ICOLD [37] state that if the PGA value is greater than $0.25 \mathrm{~g}$ and the energy source is closer than $10 \mathrm{~km}$ from the dam site, it is classified as hazard class IV with hazard rating of extreme.

Throughout this study, two methods have been considered to quantify the total risk for dam structures. In DSI guidelines, total risk factor depends to reservoir capacity, height, evacuation requirement and potential hazard [33]. According to DSI Guidelines all dams are categorized in IV risk classes with very high risk rating. Following Bureau's method, all large dams are classified in risk class III, a very high-risk rating. In Bureau method, the values of the TRF range from 126.4 to 192.3 (Table 2).

\section{Discussions}

Safety concept for cascade dams should be different from that of a single dam. The failure of any dam in a cascade structure can result to overtopping or failure of the downstream dam or dams. In this study, the selected dams, which are critical structures for their own basins, were analyzed and then evaluated as given below: 
The Ataturk dam is a zoned rockfill dam on the Euphrates River, located in the southeastern portion of Turkey. The 169$\mathrm{m}$ height dam has the largest reservoir of Turkey with $48700 \mathrm{hm}^{3}$. Its crest length is $1670 \mathrm{~m}$ and base width is approximately $900 \mathrm{~m}$. Its active storage capacity is $11000 \mathrm{hm}^{3}$ It is located $35 \mathrm{~km}$ north of the Birecik dam reservoir and $120 \mathrm{~km}$ south of Karakaya dam body. Its main embankment construction was started in 1985 and completed in 1995. The reservoir level has maximally reached to $537 \mathrm{~m}$ up to now. Its level fluctuates from 526 to $535 \mathrm{~m}$ as based on climate change and energy demand. It was designed a multi-purpose structure for irrigating lands, producing electricity and providing flood control. It generates electricity of $8900 \mathrm{GWh}$ per year with an installed capacity of $2400 \mathrm{MW}$. Tosun and Oguz [17] introduced more comprehensive information about its seismic stability. According to this study, the slopes are safe, even if considered the Bozova fault system, for seismic coefficient k-value determined by conventional analyses. Tosun [14] introduces the results of a study, titled as "Re-analysis of Ataturk dam under ground shaking by finite element models" which was performed for the Atatürk dam in Turkey. Tosun [38] and Tosun and Oguz [39] evaluate its total risk on cascade structure of Lower Euphrates basin.

Keban dam is the highest structure with a height of $207 \mathrm{~m}$ in the basin and has the second largest reservoir with 31000 hm3 in Turkey. It is a key structure for general stability of Euphrates ba-sin. It was designed as a composite type consisting of rockfill embankment at the right side and concrete gravity body at the left side. The dam was entirely completed in 1975 . The active storage capacity is $13927 \mathrm{hm} 3$. Tosun [15] assessed its embankment stability in his paper, namely "earthquake safety evaluation of Keban dam, Turkey". Tosun et al (2007) stated that Its Total Risk Factor (TRF) value is 167.8, and it is identified as risk class of III and pointed out that it has high risk potential for downstream life and structures. These results were confirmed by those obtained from the study of Tosun and Oguz [39). They emphasized the fact that this 36-years old compo-site type with rockfill embankment and gravity dam is in excellent condition. They recommended its seismic upgrade as soon. Authors recommend that the operation programs of Keban and Ataturk dams should have confirmed to each other.

The Ilisu dam is a concrete faced rockfill dam on the main river of Tigris Basin. It has a 130-m height from river bed. When the reservoir is at maximum capacity, the facility impounds $10400 \mathrm{hm}^{3}$ of water with a reservoir surface area of 309 $\mathrm{km}^{2}$. Its construction was commenced in 2006 and finished in 2020. It was designed to generate electricity with a install capacity of $1200 \mathrm{MW}$. The main embankment consists of crushed rock and transition zone to concrete face. The upstream and downstream fills are large-sized crushed rocks at which the most durable and high strengthened ones are located on the outer part of the shell. The crest length is $2289 \mathrm{~m}$ and the side slopes of main embankment is $1.4 \mathrm{H}: 1 \mathrm{~V}$ for upstream and downstream $(\mathrm{H}=$ horizontal and $\mathrm{V}=$ vertical). According to the seismic hazard analyses of this study, it will be subjected to a peak ground acceleration of $0.168 \mathrm{~g}$ by an earthquake of 6.8 magnitude. It seems safe for earthquake conditions as a result of pseudo-static analyses, when considered the k-values, which are calculated according to mean peak ground acceleration at the $50^{\text {th }}$ percentile. It is identified as class III with high risk. Dam site is located on safe area when considered seismicity of dam site. It has longest crest length for concrete faced rockfill dam in the world. Author thinks that it can pose arching problem in first impounding process and gap occurrence between rockfill zone and faced concrete slab during operation stage. It can also have settlement problem in long-term period.

The Catalan dam is a earthfill dam on main river in the Seyhan basin. It has a $82.0 \mathrm{~m}$ height from foundation. When the reservoir is at maximum capacity, the facility impounds $2120 \mathrm{hm}^{3}$ of water with a reservoir surface area of $84.5 \mathrm{~km}^{2}$. Its construction was finished in 1996. It is a multi-purpose project to provide domestic water with annual capacity of $236 \mathrm{hm}^{3}$, to irrigate land of 3686 ha and to produce electricity with an installed capacity of $168.9 \mathrm{MW}$. The crest length is $834 \mathrm{~m}$ and the side slopes of main embankment is $4.0 \mathrm{H}: 1 \mathrm{~V}$ for upstream and $3.0 \mathrm{H}: 1 \mathrm{~V}$ for downstream $(\mathrm{H}=$ horizontal and $\mathrm{V}=$ vertical) (Figure 3). On the section there is a central impervious core, which is composed of compacted impervious clay and transition sections of sandy and gravelly aggregates was used between the core and semi-pervious soils for both sides. The alluvium on river bed, which is composed of different size of river bed material, was removed before beginning the construction of the main embankment. According to the seismic hazard analyses of this study, it will be subjected to a peak ground acceleration of $0.102 \mathrm{~g}$ by an earthquake of 5.7 magnitude and its embankment is only $2.4 \mathrm{~km}$ far away from an active fault given in new seismo-tectonic map of Turkey in 2014. Its TRF value is 183.6, and it is identified as risk class of III. This 23-year old earthfill embankment is in excellent condition. However, it is most critical structure of the Lower Seyhan basin for downstream life and properties. Therefore, its seismic upgrade should be provided soon. 
Menzelet dam is a embankment type consisting of rockfill and earthfill. The 150-m high dam with a total embankment volume of $8700000 \mathrm{~m}^{3}$ is located on the main river of Ceyhan basin. Its construction was finished in 1992. When the reservoir is at operation stage with maximum water level, the facility approximately will impound $1975 \mathrm{hm}^{3}$ of water with a reservoir surface area of $42 \mathrm{~km}^{2}$. It was mainly designed to produce electricity with $124 \mathrm{MW}$ (DSI, 2016). The side slopes of main embankment is $2.5 \mathrm{H}: 1 \mathrm{~V}$ for upstream and $2.0 \mathrm{H}: 1 \mathrm{~V}$ for downstream (H=horizontal and $\mathrm{V}=$ vertical). On the section there is a central impervious core, which is composed of compacted low plasticity clay and a transition sections of sand and were designed between the core and earthfill material for downstream. The 14-m thick alluvium on river bed was removed before beginning the construction of the main embankment beneath the clay core and slurry trench technique was used to provide impermeability for cofferdams. The seismic hazard analyses performed throughout this study indicates that Menzelet dam is one of one of the critical structures within the basin. It will be subjected to a peak ground acceleration of $0.206 \mathrm{~g}$ by an earthquake of 6.1 magnitude and it is located within the shear zone of Eastern Anatolian Fault. It is also classified into the risk class of III with high risk. However, it impacts the stability of other cascade dams located on downstream with huge reservoir capacity. In other word, it has a potential hazard for the existing downstream structures (Kilavuzlu, Sir and Kandil dams).

The Kilickaya dam is a rockfill dam with central clay core on the main river of Yesilirmak Basin. It has a 103-m height from river bed. When the reservoir is at maximum capacity, the facility impounds $1400 \mathrm{hm}^{3}$ of water with a reservoir surface area of $65 \mathrm{~km}^{2}$. Its construction was finished in 1990. It was designed to generate electricity with a install capacity of 124 MW. The side slopes of main embankment is $2.5 \mathrm{H}: 1 \mathrm{~V}$ for upstream and $2.0 \mathrm{H}: 1 \mathrm{~V}$ for downstream (H=horizontal and $\mathrm{V}=$ vertical) (Fig.3). On the section there is a central impervious core, which is composed of compacted low-high plasticity clay and a transition section of sand, gravel and small-sized crushed rock was designed between the core and rockfill materials for downstream and upstream parts. The alluvium on river bed, which is composed of mixtures of fine to large size grains, was removed before beginning the construction of the main embankment. The maximum depth of cut-off trench is $31 \mathrm{~m}$. A general view from Kilickaya dam is given in Fig. 4. The seismic hazard analyses performed throughout this study indicates that Kilickaya Dam is the most critical dam within the basin. It will be subjected to a peak ground acceleration of $0.583 \mathrm{~g}$ by an earthquake of 7.4 magnitude and it is $7.8 \mathrm{~km}$ far away from the fault segment in the shear zone. Tosun [40,41,42] introduces more detail evaluation about its seismic stability and total risk in the cascade system of Yesilirmak basin.

Altınkaya dam is also a rockfill type as that of Kilickaya dam. The 195-m high dam is located just at the end of cascade system of Kizilirmak river. Its construction was finished in 1988. When the reservoir is at operation stage with maximum water level, the facility approximately will impound $5763 \mathrm{hm}^{3}$ of water. On the section there is a central impervious core, which is composed of compacted clay. A transition section of sand, gravel and crush rock is designed between the core and pervious materials. The seismic hazard analyses performed throughout this study indicates that Altinkaya dam is the critical structure within the basin when considered total stability of cascade system and downstream life. It will be subjected to a peak ground acceleration of $0.179 \mathrm{~g}$ by an earthquake of 6.1 magnitude and it is far away $10.8 \mathrm{~km}$ from secondary segment of North Anatolian Fault. It is also classified into the risk class of II with moderate risk. However, its total risk is high for downstream life.

\section{Conclusion}

Cascade dams affect river hydrology as well as public safety of people living downstream. Safety assessment for cascade dams should be different from that of a single dam. The appropriate design measures should be considered to obtain rational solution to the problem such as catastrophic release of water from the reservoir. In this study, seven large dams, which are the critical structures in their own cascade systems, are analysed and evaluated considering as seismic hazard and total risk concepts. The study indicates that Ataturk and Kilickaya dams have high hazard when compared with others considered in study. However, all dams are the critical structures for their own cascade system and also pose high total risk for downstream life and properties. Keban dam, which is the second largest dam of Turkey with a storage capacity of $31000 \mathrm{hm}^{3}$, is the key structure for the upstream dams and their appurtenant structures. Ataturk dam, which has a huge storage capacity of 44700 $\mathrm{hm}^{3}$, is critical structure for downstream dams. Author suggests that the operation program of Keban should be executed as considering that of Ataturk dam. Ilisu dam has both functions of Keban and Ataturk dams mentioned above for Tigris cascade 
system. Altinkaya, Catalan, Kilickaya and Menzelet dams are also critical structures for downstream dams on their own basins. A special safety program should be developed for entire critical dams discussed above to make out defects about cracks, unacceptable seepage and leakage, loss of freeboard, settlement, fault movement, etc. However, a meaningful specification should be prepared before beginning to execution of this safety program

\section{References}

[1] H. Tosun, "Seismic studies", International Water Power \& Dam Construction, 58 (2), 20-23, 2006.

[2] H.Tosun, İ. Zorluer, A.Orhan, E.Seyrek, H.Savaş, M.Türköz, "Seismic hazard and total risk analyses for large dams in Euphrates basin, Turkey”, Engineering Geology 89 (1-2), 155-170, 2007.

[3] H.Tosun, "Total Risk Analysis of Dam and Appurtenant Structures in a Basin and a Case Study" International Congress in River Basin Management, Volume I, 22-24 March, Antalya, 477-488, 2007.

[4] H.Tosun,M. Türkoz, \& H.Savas, River basin risk analysis. Int. Water Power and Dam Construction, May issue, 2007.

[5] H. Tosun, "Evaluating Earthquake Safety for Large Dams in Southeast Turkey", Hydro Review Worldwide (HRW), 3440, 2008.

[6] H.Tosun, T.V.Tosun, Total risk and seismic hazard analyses of large dams in northwest Anatolia, Turkey. ICOLD $85^{\text {th }}$ Annual Meeting, July 3-7, Prague, 2017.

[7] H.Tosun, T.V.Tosun, M.A. Hariri-Ardebili, "Total risk and seismic hazard analysis of large embankment dams: case study of Northwest Anatolia, Turkey" Life Cycle Reliability and Safety Engineering, 1-10, 2020 (https://doi.org/10.1007/s41872-020-00113-4).

[8] H.Tosun, H.Savas, "Seismic hazard analyses of concrete dams in Turkey", in Proceeding of CDA Conference, 2005.

[9] H. Tosun, "Hazard and Total Risk Analyses of Large Dams under Threat of the North Anatolian Fault Zone in Mid Anatolia, Turkey" 5th World Congress on Civil, Structural, and Environmental Engineering (CSEE'20), October 2020, DOI:10.11159/icgre20.191.

[10] H.Tosun, M.Turkoz, S.Savas, E.Seyrek, "River basin risk analysis", International Water Power and Dam Construction, 59 (5), 30, 2007.

[11] H.Tosun, M.Turkoz, "Total risk-analyzing methods for dam structures and a case study in Turkey", in Proceeding of CDA Annual Conference, 2007.

[12] H.Tosun, E.Seyrek, "Total risk analyses for large dams in Kizilirmak basin, Turkey", Natural Hazards and Earth System Sciences, 10 (5), 979, 2010.

[13] E.Seyrek, H.Tosun, "Deterministic approach to the seismic hazard of dam sites in Kizılırmak basin, Turkey" Natural hazards, 59 (2), 787, 2011.

[14] H.Tosun, "Re-analysis of Ataturk Dam under Ground Shaking By Finite Element Models", in Proceeding of CDA Annual Conference, September 22-27. Saskatoon, Canada, 2011.

[15] H.Tosun, "Earthquake Safety of Keban Dam, Turkey", in Proceeding of CDA Annual Conference, October 15-20. Fredericton, NB, Canada, 2012.

[16] E.Seyrek, H.Tosun, "Influence of analysis methods for seismic hazard on total risk of large concrete dams in Turkey", Gazi Univ, J.Fac Engineering Architecture, 28-1, 67-75, 2013.

[17] H.Tosun, S.Oguz, "Stability Analysis of Atatürk dam, Turkey as Based on the Updated Seismic Data and Design Code", in Proceeding of 85th Annual Meeting of International Commission on Large Dams, Prague, 66-66, 2017.

[18] T.V. Tosun, H.Tosun, "Total Risk and seismic hazard analyses of large dams in Northwest Anatolia, Turkey" in Proceeding of 85th Annual Meeting of International Commission on Large Dams, Prague, 165-165, 2017.

[19] H Tosun, T.V Tosun "Dynamic Analysis of Embankment Dams Under Strong Seismic Excitation and a Case Study", in Proceeding of Long-Term Behaviour and Environmentally Friendly Rehabilitation Technologies of Dams (LTBD 2017), Tehran, 2017, https://doi.org/10.3217/978-3-85125-564-5-102.

[20] H.Tosun, "Safety Assessment of Large Reservoir Constructed for Domestic Water Near Urban Areas and a Case Study", in Proceeding of ICOLD-ATCOLD Symposium on Hydro Engineering, Wien, 917-927, 2018

[21] W.A.Fraser, J.K.Howard, "Guidelines for Use of the Consequence-Hazard matrix and Selection of Ground Motion Parameters”, Technical Publication, Department of Water Resources, Division of Safety of Dams, 2002. 
[22] M.J.Jiminez, D.Giardini, G.Grünthal, "Unified Seismic Hazard Modelling throughout the Mediterranean Region”, Bolettino di Geofisica Teorica ed Applicata, Vol.42, N.1-2, Mar-Jun., 3-18., 2001.

[23] K.W. Campbell, "Near-Source Attenuation of Peak Horizontal Acceleration" Bulletin Seism. Soc. Am., V.71, N.6, 2039-2070, 1981.

[24] D.M. Boore, W.B.Joyner, T.E.Fumal, "Estimation of response spectra and peak accelerations from Western North American earthquakes", An interim report. Open file report 93-509.U.S.G.S, 1993.

[25] N.N.Ambraseys, "The Prediction of Earthquake Peak Ground Acceleration in Europe", Earthquake Engineering and Structural Dynamics, V.24, 467-490, 1995.

[26] D.M.Boore, W.B. Joyner, T.E.Fumal, "Equation for Estimating Horizontal Response Spectra and Peak Acceleration from Western North American Earthquakes”, A Summary of recent Work. Seismological Research Letters, V.68, N.1, January /February, 128-153, 1997.

[27] P.Gulkan, E.Kalkan, “Attenuation modeling of recent earthquakes in Turkey”, Journal of Seismology, 6(3), 397-409, 2002.

[28] E.Kalkan, P.Gulkan, "Site-Dependent Spectra Derived from Ground Motion Records in Turkey", Earthquake Spectra, 20, 4, 1111-1138, 2004.

[29] S.L.Kramer, 1996. “Geotechnical Earthquake Engineering” Prentice-Hall, Upper Saddle River, NJ 653 p.

[30] E.Krinitzsky, "Discussion on Problems in the Application of the SSHAC Probability Method for Assessing Earthquake Hazards at Swiss nuclear power plants". Eng. Geol. 78 285-307; Eng.Geo. 82, 62-68. 2005.

[31] FEMA. "Federal Guidelines for Dam Safety-Earthquake Analyses and Design of Dams"2005.

[32] ICOLD. "Selecting Seismic Parameters for Large Dams-Guidelines ”. ICOLD, Bulletin 148, 2016.

[33] DSI, "Selection of Seismic Parameters for Dam Design”, State Hydraulic Works, Ankara, 29 p, 2012 (in Turkish).

[34] G.J. Bureau, "Dams and Appurtenant Facilities in Earthquake Engineering Handbook" edited by Chenh, W.F and Scawthorn, C. CRS press, Bora Raton 26.1-26.47, 2003.

[35] General Directorate Of Mineral Research And Explorations (MTA), Geoscience Map Viewer and Drawing Editor, http://yerbilimleri.mta.gov.tr/

[36] DSI, Dams of Turkey. TR-COLD, Ankara, 602 p, 2016.

[37] ICOLD, "Selecting Parameters for Large Dams-Guidelines and Recommendations", ICOLD Committee on Seismic Aspects of Large Dams, Bulletin 72, 1989.

[38] H.Tosun, "Earthquakes and Dams", in Earthquake Engineering - From Engineering Seismology to Optimal Seismic Design of Engineering Structures, edited by Abbas Moustafa, IntechOpen, May 2015, (https://doi.org/10.5772/59372 ).

[39] H.Tosun and S. Oguz, "Seismic Design for Existing Large Dams and Case Studies" in Proceeding of 11 ${ }^{\text {th }}$ ICOLD European Club Symposium Chania, Crete, 2-4 October 2019.

[40] H.Tosun, "Seismic Stability of Large Dams Located Near Energy Source And A Case Study"

in Proceeding of 5th International Conference on Earthquake Engineering and Seismology, METU-Ankara 8-11 October 2019.

[41] H.Tosun, "Earthquake Safety Evaluation for Large Dams Located near the Energy Source and Case Studies", in Proceeding of 11th ICOLD Europen Club Symposium, Chania, Crete 2-4 October 2019.

[42] H.Tosun, "Hazard and Total Risk Analyses of Large Dams under Threat of the North Anatolian Fault Zone in MidAnatolia, Turkey" in Proceeding of 5th World Congress on Civil, Structural, and Environmental Engineering (CSEE'20) Virtual Conference - October 2020 (https://doi.org/10.11159/icgre20.191). 